amatetir. It must happen that the professor (so called) will be constrained to give up the whole of his time to the duty which is most expected of him, and that original research will suffer both in quantity and in quality. The most general principles of political economy are sufficient to show that in a wealthy and moderately enlightened country the remuneration of teaching had better be regulated by the equitable standard which impartial competition will not fail to establish. It is for those subjects which, though of cssential importance to the welfare of the country, are in themselves nzturally unremunerative, that the old endowments for the promotion of education and knowledge, whatever may have been the particular means by which these ends were originally to be attained, are now required. Among these subjects disinterested application to pure Science is manifestly the chief.

In a subsequent article we propose to show that the funds of the Colleges cannot be more consistently applied than to this purpose, and that the progressive well-being of the Universities mainly depends upon the degree to which they are concerned in the advancement of know. ledge.

C.

\section{THOME'S LEHRBUCH DER ZOOLOGIE}

Lehrbuck der Zoologie. Von Dr. Otto Wilhelm Thómé; Pp. 416. (Brunswick: I872.)

IF Germans wonder, not without reason, who buy our $1 \mathrm{~m}$ anuals of microscopic mountin 5 , Englishmen may equally wonder for whom such books as Dr. Thomés are written. We have technical treatises on special branches of zoology, and we have popular natural history books, but a manual like this would find a poor sale in England. It is a school manual, and its existence is explained by the introduction of zoology to some extent into the curriculum of the German gymnasia and much more into that of the Realschule, which more or less correspond to the "modern side" of our public schools, or may be described as answering in intention, though of course immeasurably superior in performance, to English "commercial schools." Whether zoology ought to form a regular part of school work, even where room is made by giving up Greek altogether and Latin more or lass, is an important question. As a part of education in the proper sense of the word, it is so inferior in exactness, in con. ciseness, in facility of demonstration, and convenience for observation and experiment to such rivals as botany, physics, and even chemistry, that its claims may practically be ignored. Moreover, looking at school work from another point of view, it is obvious that any scheme of utilitarian instruction which is good for much must include ignorance of the greaterpart of human knowledge, in order to provide for acquaintance with the rest; and the first addition to the indispensable elements of reading, writing, and arithmetic would probably be claimed for geography, political economy, or the rudiments of hygicne, as more useful branches of knowledge than zoology. A boy with a bent for natural history would gain far more good from reading the bits of zoology in such books as the "Voyage of the Beagle," the "Malay Archipelago," or "Kosmos," and by collecting bird's eggs or butterfies, than he would by painfully wading through the details of $D r$.
Thomés closely pririted pages. And when zoology is taken up as a serious study by older students, most teachers will agree that the best plan is for them to begin by a careful study of a particular branch of the subject, with the help of such a handbook as Flowers" "Osteology of the Mammalia."

Looking to the object of the book, the reader will find Dr. Thomés work fairly done. The first hundred pages are devoted to a popular sketch of human anatomy and physiology, from which all notice of generation and development is cxcluded. Otherwise it is as complete as the space will allow. The remainder of the book describes the several classes of animals, beginning with Mammalia and following the arrangement into seven types-Vertebrata, Mollusca, Arthropoda, Vermes, Echinodermata, Colenterata and Protozoa-which is now generally accepted among German naturalists. A diagram of these types is given, which might serve for a genealogical trce; but no hint of this intention is given. The sub-division into classes and orders is not particu. larly good. Thus among Mammalia the Sirenia are confounded with the Cetacea, Ray's obsolete distribution into Ungulata and Unguiculata is preserved, and the orders Ruminantia and Pachydermata appear, as if nothing had been done to clear up the real affinities of these groups since Cuvier published the "Regne Animal." The classification of birds is not more unsatisfactory than that of other writers; and in the class of fishes Müller's orders are commendably followed. Tunicata and Bryozoa are of course excluded from Mollusca, and help to fill the lumber-room of Vermes. A very large share is, as usual, given to the account of insects, while marine zoology and the Protozoa receive comparatively little attention.

Three hundred and fifty-eight woodcuts'make!an important feature of the work. Most of these are good in themselves and well printed. Those illustrating human anatomy and histology are the best, and almost all borrowed from Henle. No indication of this or any other source is given, but it is easy to recognise that some of the figures have been taken from the admirable cuts in Bell's "British Reptiles," others from Forbes, Milne-Edwards, and other wellknown works; while some of the Mammalia appear to have been drawn from children's toys. Fig. 350, of a sponge, is a curiously modified reproduction of the original drawing in Grant's "Outlines of Comparative Anatomy" (p. 312). Of the thirty-one figures of birds, twenty-seven represent European species, and of these all but four are copied from Yarrell's British Birds. One excellent addition to each figure is a note of the relation it bears to the actual size of the animal represented, or of the average length of the latter. There are not many figures of anatomical details, but almost all are good, some being taken from Gegenbaur's "Vergleichende Anatomie."

To compare Dr. Thome's book as a whole with serious scientific treatises even of the second class, like that of Claus, would be unfair : but even as a "cram-book" it is inferior to Nicholson's Zoology: and it gives far too little space to descriptions of the habits and character of well-known groups like mammals, birds, and insects, to be really popular. Such books as Knight's "Museum of Animated Nature" are much more interesting and quite as scientific.

P. S. 